\title{
専門医症例報告
}

\section{上顎前歯顎堤吸収部への骨移植とインプラント補綴により 発音障害を改善した症例}

\author{
羽鳥弘毅 \\ Improvement of articulation disorders by implant restoration for maxillary anterior missing teeth \\ following autogenous bone grafting \\ Kouki Hatori
}

抄 録

症例の概要：43 歳の男性。上顎前歯部接着ブリッジによる発音障害を主訴として来院した。 X 線 CT 画像にて 欠損部唇側歯槽骨の著しい吸収が認められ，オトガイ部からの自家骨移植後にインプラント補綴治療を行った。 考察：顎堤形態および歯列口蓋側面形態からなる固有口腔形態の対称性は，発音機能に大きく関与しており， それらの異常は発音障害の一因となる。そのため本症例では，上部構造口蓋側面形態は，発音時の舌接触を考 慮し顎堤からの移行部を含めて可及的に左右対称となるように調製，またセメント固定を採用することにより， 発音障害の改善および舌感の向上が得られた。

結論：口蓋側面形態の考慮により発音機能の改善を得た。

キーワード

発音障害，自家骨移植，インプラント，固有口腔

\section{ABSTRACT}

Patient: A 43-year-old male patient complained of articulation disorders after the placement of an adhesion bridge to restore maxillary anterior missing teeth. Since severe bone resorption was detected by X-ray CT in the edentulous region, implant prosthetic treatment was performed following autogenous bone grafting. Finally, the edentulous space was restored with an implant-supported fixed prosthesis.

Discussion: Symmetry of the oral cavity proper, consisting of alveolar ridge form and palatal wall of the dental arch, is closely related to articulation function, therefore abnormalities of anterior palatal form can cause articulation disorders. In this case, the palatal wall of the superstructure was fabricated to be as symmetrical as possible, taking tongue function into consideration. Since the superstructure was fixed with cementation, improvement of articulation and comfort of the tongue were obtained.

Conclusion: Improvement of articulation was achieved by symmetrical restoration of the oral cavity proper.

Key words:

Disorders of articulation, Autogenous bone grafting, Implant, Oral cavity proper

東北大学大学院歯学研究科口腔機能形態学講座口腔システム補経学分野

Division of Advanced Prosthetic Dentistry, Tohoku University Graduate School of Dentistry

受付 : 2015 年 5 月 18 日/受理 : 2015 年 12 月 5 日

Received on May 18, 2015/Accepted on December 5, 2015 


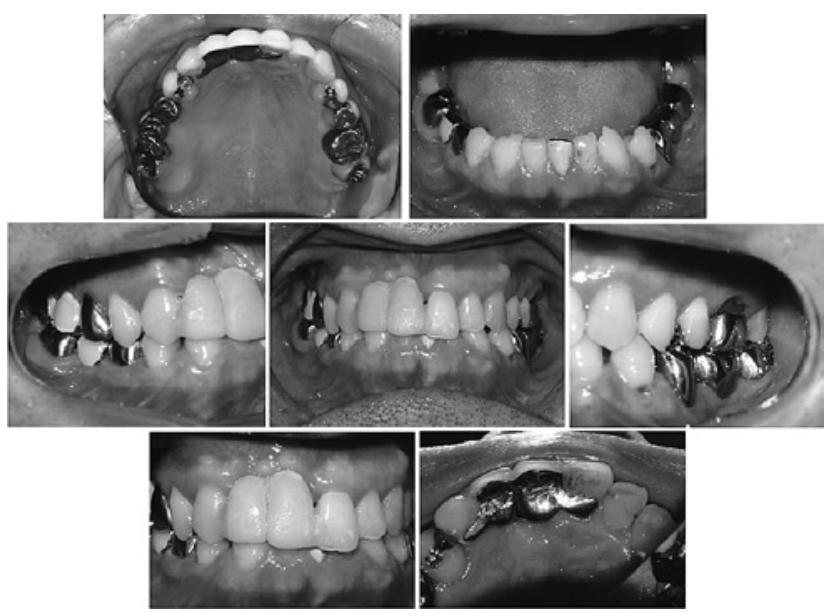

図 1 Intraoral views at the first examination and adhesion bridge

初診時の口腔内写真および接着ブリッジ

\section{I 。緒言}

発音障害の原因は主に中枢性と末梢性に大別され る ${ }^{1)}$ 。末梢性発音障害の要因として，構音器官である

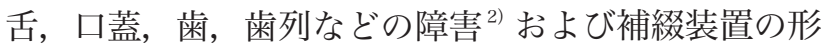
態不良 ${ }^{3)}$ などが挙げられる。 今回，歯根破折による抜 歯後の顎堤吸収部位に対して装着された接着ブリッジ の口蓋側面形態不良に起因する発音困難を訴える患者 に対して，骨移植およびインプラント補綴治療を適用 することにより発音障害の改善および舌感の向上が認

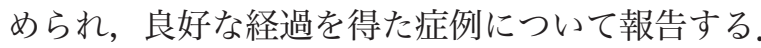

\section{II. 症例の概要}

患者：43 歳（初診当時), 男性.

初診日：2007 年 2 月 6 日.

主訴：前歯とべロの当たりが気になって話しづらい. 既往歴：花粉アレルギー (軽度).

現病歴：2003 年に 21 歯根破折による抜歯後，近 医歯科医院にて接着ブリッジによる補綴治療を受けた が,装着後より発音困難を自覚した. 2007 年 2 月 6 日, 発音困難を主訴に本院へ来院した。

現症：当科初診時，残存歯数は 24 本で，2侁天 欠如， $7 / 7$ に近心傾斜を認めた。また下顎両側犬歯と 第一小臼歯間に空隙を認めた。オーバーバイトは約 $5 \mathrm{~mm}$ ，オーバージェットは約 $3 \mathrm{~mm}$ でスピーの彎曲 は右側が左側に比べて強く，咬合様式はグループファ ンクションであった。複数歯において歯冠補綴装置が 装着されていた。 21 の接着ブリッジは，歯冠長が長 く歯頸線の位置が支台歯歯頸線より低位であった。ま

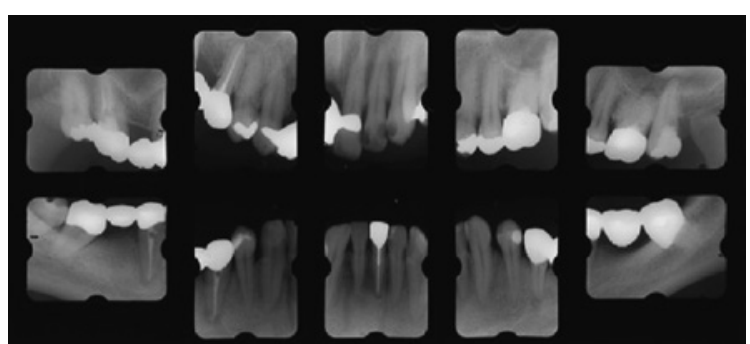

図 2 Radiographs at the first examination 初診時のデンタル X 線写真

表 1 Periodontal conditions at the first examination 初診時の歯周組織検査結果

\begin{tabular}{|c|c|c|c|c|c|c|c|c|c|c|}
\hline bytax & 0 & \begin{tabular}{l|l}
0 & 0 \\
\end{tabular} & & 0 & 0 & 0 & 0 & 0 & 0 & 0 \\
\hline 轸整 & 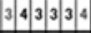 & 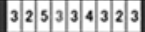 & & 323 & \begin{tabular}{l|l}
32 & 3 \\
\end{tabular} & 32. & $4 \sqrt[3]{3}$ & \begin{tabular}{ll|l}
32 & 4
\end{tabular} & $\sqrt[3]{3} 3$ & $3 \sqrt{35}$ \\
\hline 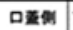 & 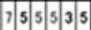 & 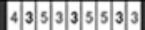 & & $\sqrt[3]{3}$ & $\sqrt[333]{3}$ & 3/3: & 23 & 324 & 33 & $3 \sqrt{44}$ \\
\hline & 8 & 5 & & 1 & 2 & $\frac{1}{3}$ & 4 & 5 & 6 & 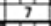 \\
\hline 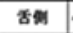 & \begin{tabular}{|l|l|l|l|l|l|}
4 & 5 & 5 & 3 & 3 & 3 \\
\end{tabular} & \begin{tabular}{|l|l|l|l|l|l|l|l|}
3 & 3 & 3 & 3 & 3 & 3 & 3 & 3 \\
\end{tabular} & 3 & $\sqrt[3]{3}$ & $\begin{array}{l}3 \sqrt[3]{3} \\
-12\end{array}$ & $3 \sqrt[3]{3}$ & 33 & \begin{tabular}{l|l|l}
4 & 3 \\
\end{tabular} & & $\sqrt[3]{3}$ \\
\hline 轻受 & \begin{tabular}{|l|l|l|l|l|}
4 & 4 & 4 & 3 & 3
\end{tabular} & 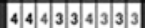 & 3 & $4 \sqrt[34]{4}$ & $\sqrt[3 \sqrt{3} 3]{3}$ & 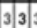 & $\begin{array}{l}4 \sqrt[3]{3} \\
-3\end{array}$ & \begin{tabular}{|l|l|l}
3 3 3 \\
\end{tabular} & & 4 \\
\hline bo挜量 & 0 & 0 & 0 & 0 & 0 & 0 & 0 & 0 & & 0 \\
\hline
\end{tabular}

た，支台歯である $3 \mid 1$ はほとんど支台歯形成されてい なかったため，接着ブリッジのフレームワークは形態 不良で, 清掃性に劣っていた(図 1)。咬合高径, 下顎位, 咬合位および顎機能に異常は認められなかった。

検査結果：デンタル X 線画像検査では，全顎的に 中等度の水平性骨吸収を認め, 77近心には垂直性骨 吸収を, また $5 \mid 1$ には根尖部周囲の透過像を認めた (図 2). 歯周組織検査では, 全顎的に $3 \mathrm{~mm}$ 以上の歯周 ポケットを認め, 大臼歯部では $5 \mathrm{~mm}$ 以上の歯周ポ ケットが認められた（表 1)。 日本語 100 音節を用い た発語明瞭度検査では，発語明瞭度は 89\%を示した。 不明瞭を示した発語は「夕行」,「ザ行」および「ダ行」 などの歯音・歯茎音であった。これらの音は静的パラ トグラムにおいて舌尖音に分類されることから ${ }^{3)}$ ，舌 尖と口蓋および前歯部口蓋側面との接触関係不良が強 く疑われた。既往歴および医療面接から中枢性発音障 害を疑うような症状・徵候は認められなかった。

診断：21補綴装置形態不良および顎堤吸収による 発音障害.

\section{III．治療内容と経過}

\section{1. 治療方針}

欠損部の補綴治療に対する選択肢として，ブリッジ を用いた固定性補緅装置, 可撤性部分床義歯あるいは インプラントを用いた固定性補綴装置による治療を患 者に提示した。それぞれの治療の利点・欠点・危険性 などについて十分な説明を行ったところ，患者はイン プラントによる補綴治療を希望した。そこで治療計画 として, 口腔衛生指導および歯周治療, 自家骨移植の 


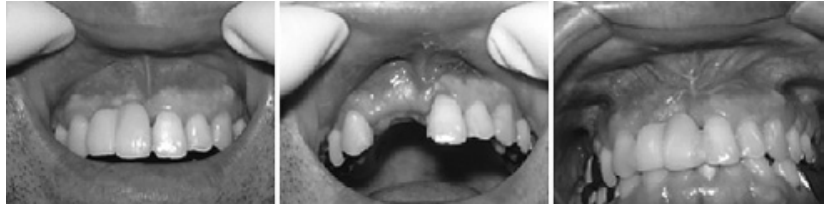

図 3 Morphological changes of residual ridge (left: at the first examination, middle: after autogenous bone grafting, right: after relaxation incision) 自家骨移植術前後の顎堤形態（左：初診時，中：自家骨 移植術後, 右 $:$ 減張切開後)

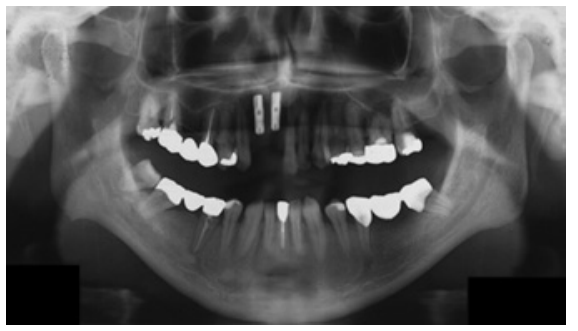

図 4 Panoramic radiograph after the implant placement 一次手術後のパノラマ X 線写真

必要性を含めたインプラント補綴治療，メインテナン スを実施していくこととし，これら治療方針に対し， 患者からは術前にインフォームドコンセントを得た。

\section{2. 処置内容}

2007 年 2 月から本院歯周病科担当医による歯周治 療が開始された。同年 7 月の X線 CT 画像検査では, 本院歯科放射線科担当医より，21 尔損部の唇側歯槽 骨吸収による陥凹と骨量不足によるインプラント植立 困難が指摘された。そこでインプラント一次手術に先 立ち，インプラント体埋入部の骨造成のため自家骨移 植術が必要であることを患者に説明し，同意を得た。 2008 年 1 月にオトガイ部からの骨移植術を実施し, 移植骨片は日本ストライカー社製ライビンガーオート パイロットスクリュー 直径 $2.0 \times$ 長さ $7.0 \mathrm{~mm} 1$ 本を 用いて固定した。骨移植術後の顎堤形態の変化に伴い, 顎堤粘膜上に接着ブリッジ基底面による加圧部を適合 試験材にて認めたため，接着ブリッジ基底面を一層削 除することにより形態修正を行った。同年 6 月に減 張切開および上唇小帯切除術を実施した（図 3)。

同年 8 月，自家骨移植片固定用スクリュー除去 後，21 尔損部に Astra ${ }^{\circledR}$ 社製 Micro Thread ST 4.0× $13 \mathrm{~mm}$ インプラント体を 2 本埋入する一次手術を実 施した（図 4)。骨移植後同様に接着ブリッジ基底面 の形態修正を行った。2009 年 1 月に二次手術を実施 し, 直径 $4.0 \times$ 高さ $3 \mathrm{~mm}$ のヒーリングアバットメン 卜を 2 本装着した。以上の自家骨移植術からインプラ ント二次手術までは本院の同一口腔外科担当医が施術 した。同年 2 月に上部構造精密印象ならびに咬合採得

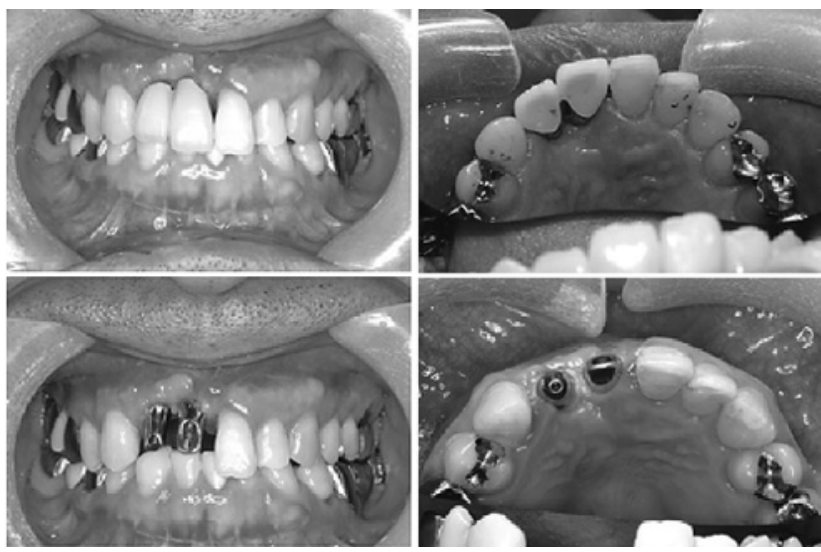

図 5 Intraoral views at the completion of superstructure 上部構造装着時の口腔内写真

を行い，同年 3 月に白金加金製カスタムアバットメン トおよび陶材焼付用金合金製フレームワークの試適を 行った。同年 4 月に白金加金製カスタムアバットメン トを装着し，上部構造にはアクセスホールの位置を考 慮して，陶材焼付冠（連結冠）を仮着セメントにてセ メント固定した。上部構造には中心咬合位での咬合接 触を付与した。また，側方運動時の接触滑走は付与せ ず，前方運動時は残存歯での接触滑走を参考に咬合干 渉を生じさせないよう咬合調整を行った（図 5).

3. 術後の経過

上部構造装着 1 力月後に経過観察およびメインテナ ンスを行い，その後 $3 \sim 4$ カ月毎にメインテナンス を行っている。2010 年 9 月に 77 が歯髄炎となり，歯 内療法後 (5) 6 (7) ブリッジを装着した。 さらに 2013 年 12 月， $4 ，\lfloor 7$ および 23 にカリエスを認め， $\sqrt{4}$, ７ にインレー修復処置および 23 にレジン充填処置を 行った。上部構造装着 4 年 9 力月経過時の所見では, 口腔衛生状態は良好で，インプラント周囲組織および 残存歯の歯周組織に炎症は認められず，X 線画像検査 からもインプラント周囲骨の吸収などの異常は認めら れなかった。また上部構造の破損なども認められず良 好な経過をたどっている（図 6,7）。

\section{4. 術後の機能評価}

本症例において，初診時より日本語 100 音節を用 いた発語明瞭度検査による発音評価を行っている，発 語明瞭度は，上部構造装着 1 力月後において $98 \%$, 上部構造装着より 4 年 9 力月後において $99 \%$ を示し た。初診時の評価スコアは 89\%であったことから， 


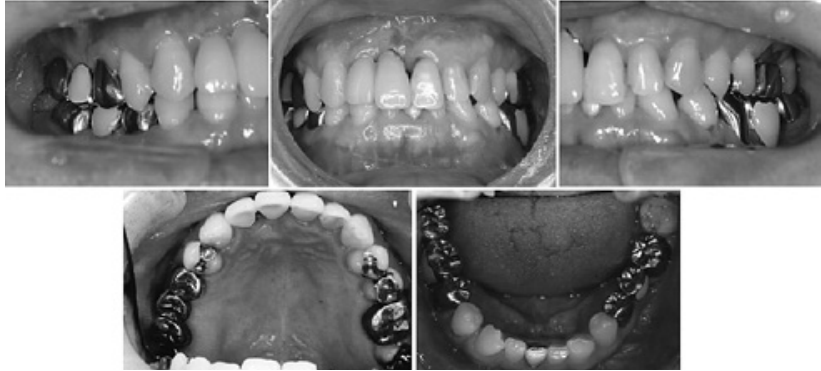

図 6 Intraoral views at 4 years and 9 months after prosthetic treatment 補経治療終了 4 年 9 力月経過時の口腔内写真

本治療により発音機能の改善を認め，現在までその機 能が維持されていることが認められた。また上部構造 装着直後から，患者は補綴装置口蓋側面の舌感改善に より滑舌がよくなったことを自覚された。

\section{IV. 考察}

本症例は，21」欠損部の顎堤吸収が唇側において顕 著で，インプラント埋入のためには骨造成による顎堤 形態の回復が必要であった。現在，骨造成法には自家 骨移植術，人工骨補填剤，歯槽骨延長術および骨再生 誘導法（GBR 法）が普及している ${ }^{2,4)}$ が，本症例では 患者の年齢，および代謝性疾患ならびに循環器疾患な ぞの既往歴がないことを考慮した上でオトガイ部から の自家骨移植術を適用し顎堤形態の回復に努めた。ま た骨移植後は, 十分な口腔前庭の深さが認められたこ とから，上唇小帯切除術と減張切開により骨移植部顎 堤形態の維持 ${ }^{2,4)}$ に努めた。 その後, インプラント一次・ 二次手術および上部構造装着から現在に至るまで，骨 移植部およびインプラント体埋入部位において良好な 長期予後が得られた。その背景には，本院でのインプ ラント治療における検査結果に基づく，各専門科担当 医等による適切な診断および処置があったものと思わ れる。

初診時の発音障害に関しては，接着ブリッジ撤去後 の $\underline{3 \mid 1}$ の舌面がほぼ天然歯の形態を呈していたことか ら，接着ブリッジのフレームワークが口蓋側でオー バーカントゥアとなり, 舌尖と口蓋側歯面・歯頸部か ら口蓋部までの領域との接触で生成される歯音・歯 菱音や舌尖音の発音障害 ${ }^{3)}$ が発現したものと推察され た。そこで本症例では，上部構造の設計および形態回 復において，エマージェンスプロファイル・基底結節 の位置などに配慮し可及的に歯列弓が左右対称となる ような口蓋側面形態を上部構造に付与した。

上部構造には，中心咬合位において対合接触を付与

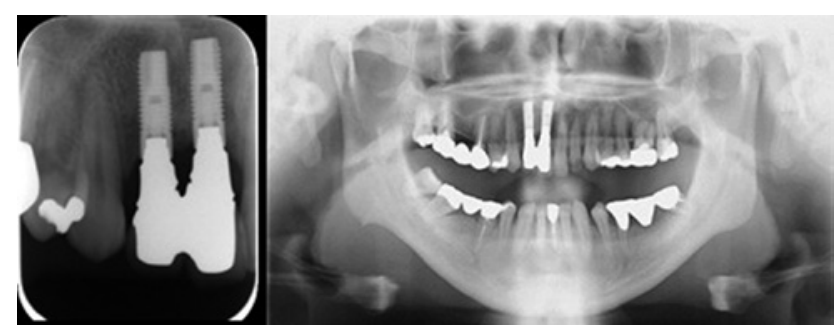

図 7 Dental and panoramic radiograph at 4 years and 9 months after prosthetic treatment 補綴治療終了 4 年 9 力月経過時のデンタルおよびパノラ マ X 線写真

し，また前方ガイドにおいては残存歯での接触滑走と 同程度の接触滑走となるよう咬合調整を行うことによ り咬合関係の機能回復に努めた。さらにアクセスホー ルの位置を考慮して上部構造の固定方法はセメント固 定を選択した。 以上より，固有口腔の形態的対称性は 発音機能に大きく関与し，現在でも良好な機能を維持 していると考えられる。

この上部構造は術者可撤式の固定方法により，リ コール時においてインプラント周囲組織およびアバッ トメントのメインテナンスを可能としている. 今後は プラークコントロールを徹底するとともに，残存歯お よびインプラント補綴部位の定期的なリコールを継続 していく予定である.

\section{V. 結 論}

補経装置の形態不良および顎堤吸収に起因する発音 困難症例に対し，自家骨移植ならびにインプラント補 綴を適用し固有口腔形態の対称性を回復することによ り良好な治療結果を得た。

\section{文献}

1）大森孝一. 声の障害と検査の概要. 日本音声言語医学会 編，新編声の検査法，東京 : 医歯薬出版 ; 2012，35-43.

2）葛西一貴。不正咬合の診断。戸塚靖則, 高戸 毅編, 口腔 科学，東京：朝倉書店；2013，554-560。

3）伊藤秀美. 床義歯口蓋部の形態形成とパラトグラフィ. 日 歯医師会誌 $2000 ; 53: 4-16$.

4）堀内克啓. インプラント外科基本技術と自家骨移植のポイ ント. 東京：クインテッセンス出版；2010，37-76.

著者連絡先: 羽鳥 弘毅

干 980-8575 宮城県仙台市青葉区星陵町 4 番 1 号

Tel: 022-717-8369

Fax: 022-717-8371

E-mail: khat810@yahoo.co.jp 